\title{
PENGARUH MEDIA SOSIAL DAN STATUS SOSIAL EKONOMI TERHADAP PERILAKU KONSUMTIF SISWA KELAS XI IPS SMA NEGERI I GUBUG
}

\author{
1'Dewi Larasati, ${ }^{2}$ Efriyani Sumastuti, ${ }^{3}$ Dwi Prastiyo Hadi, ${ }^{4}$ Mahmud Yunus \\ 1,2,3,4 Universitas PGRI Semarang \\ Alamat e-mail : dewilarasati957@gmail.com
}

\begin{abstract}
ABTRACT
This study aims to determine the effect of the use of social media and socioeconomic status on the consumer behavior of class XI IPS students of SMA Negeri 1 Gubug both commercially and simultaneously. the population in this study was 106 students with a sample of 84 students. This study uses a quantitative approach. The results of this study were obtained $Y=-8,890+0,855 X 1+0,606 X 2$. Social media simultaneously has a positive and significant effect on consumptive behavior in XI IPS students of SMA Negeri 1 Gubug. Socioeconomic status has a positive and significant influence on the consumptive behavior of SMA Negeri 1 Gubug students. Partially, social media and socioeconomic status influence consumer behavior by 0.527 meaning that the contribution of variable $X$ (independent) is social media and socioeconomic status to the $Y$ variable (dependent) consumer behavior is $52.7 \%$ while the remaining $47.3 \%$ is influenced by other variables.
\end{abstract}

Keywords: Social Media, Socio-Economic Status, Consumptive Behavior.

\begin{abstract}
ABSTRAK
Penelitian ini bertujuan untuk mengetahui pengaruh penggunaan media sosial dan status sosial ekonomi terhadap perilaku konsumtif siswa kelas XI IPS SMA Negeri 1 Gubug secara paersial maupun simultan. populasi dalam penelitian ini adalah 106 siswa dengan sampel penelitian sebanyak 84 siswa. Penelitian ini menggunakan pendekatan kuantitatif. Hasil penelitian ini diperoleh $Y=-3,890+0,855 X 1+0,606 X 2$. Media sosial secara simultan berpengaruh positif dan signifikan terhadap perilaku konsumtif pada siswa XI IPS SMA Negeri 1 Gubug. Status sosial ekonomi berpengaruh positif dan sgnifikan terhadap perilaku konsumtif siswa SMA Negeri 1 Gubug. Secara parsial, media sosial dan status sosial ekonomi berpengaruh terhadap perilaku konsumtif sebesar 0,527 artinya besar kontribusi variabel $X$ (independent) yaitu media sosial dan status sosial ekonomi terhadap variabel $Y$ (dependent) perilaku konsumtif adalah sebesar $52,7 \%$ sedangkan sisanya sebesar $47,3 \%$ dipengaruhi oleh variabel lain.
\end{abstract}

Kata Kunci: Media Sosial, Status Sosial Ekonomi, Perilaku Konsumtif.

\section{PENDAHULUAN}

Pada era globalisasi saat ini ilmu pengetahuan dan teknologi semakin berkembang pesat (Yunus, M., 2018). Teknologi pada dasarnya digunakan untuk membuat kehidupan manusia menjadi mudah dan nyaman. Perkembangan teknologi telah menyababkan bertambahnya keinginan untuk mencari pemuas kebutuhan. Pada awalnya pola pemenuhan kebutuhan merupakan cara seseorang untuk memenuhi kebutuhan hidup, namun pada masa sekarang ini berkembang menjadi bagaimana mereka ingin dipandang dalam mengikuti tren sekarang. Setiap manusia pasti melakukan kegiatan konsumsi dan kegiatan konsumsi ini dilakukan setiap hari. Tujuan dari kegiatan konsumsi adalah untuk memperoleh kepuasan setinggi-tingginya atas penggunaan barang dan jasa serta mencapai tingkat kemakmuran (Astuti, 2016).

Perilaku konsumtif kini telah berkembang dalam kehidupan sehari-hari sehingga 
membeli barang secara berlebihan menjadi sangat tidak asing lagi bagi masayarakat yang hidup di era modern seperti sekarang ini, tidak terkecuali pada siswa siswi SMA yang menginjak masa remaja. Dengan adanya teknologi informasi yang semakin canggih memberi kesempatan para produsen untuk memasarkan barang-barang mewah dan dibuat semenarik mungkin. Iklan-iklan yang ditawarkan produsen melalui media sosial dapat menarik siswa atau para remaja untuk membeli suatu produk. Media sosial lebih banyak digunakan oleh masyarakat untuk berkomunikasi dan mendapatkan informasi karena kecanggihan media sosial yang dapat menyajikan irformasi terikni, mudah dijangkau oleh masyarakat luas hanya dengan menggunakan ponsel seperti smartphone serta merupakan media yang murah (Miranda, 2017).

Selain melalui internet atau media sosial para remaja juga terpengaruh oleh lingkungan sekitar terutama lingkungan keluarganya. Salah satu faktor yang dapat mempengaruhi perilaku konsumtif siswa yaitu orang tuanya. Jika orang tua mempunyai penghasilan yang tinggi maka anak mempunyai gaya hidup yang tinggi dan anak akan cenderung diberi uang saku yang lebih untuk membeli kebutuhan yang diinginkan begitupun sebaliknya jika orang tua memiliki penghasilan yang rendah maka gaya hidup anaknya juga lebih sederhana dan uang saku yang diberikan lebih sedikit (Nikita \& Hadi 2018).

Berdasarkan hasil observasi yang dilakukan oleh peneliti pada 30 siswa di SMA Negeri 1 Gubug, pendapatan orang tua dalam sebulan adalah Rp. 2.500.000-3.500.000 dengan jumlah 10 siswa. Dalam hal ini, jika pendapatan orang tua tergolong tinggi maka orang tua siswa akan memberikan uang saku berlebih kepada siswa sehingga siswa dapat membelikan uang yang dimiliki untuk membeli barang yang mereka inginkan. Pengeluaran siswa dalam satu bulan yang paling banyak adalah Rp. 300-500 ribu perbulan dengan jumlah siswa 17. Hal tersebut dapat menunjukkan bahwa konsumsi siswa kelas XI IPS SMA Negeri 1 Gubug tergolong tinggi.

Selain pendapatan orang tua dan uang saku setiap bulan, media sosial juga sebagai media untuk bertransaksi. Siswa kelas X1 IPS SMA Negeri 1 Gubug suka membeli barangbarang secara online melalui media sosial. Hal ini bukan kebutuhan mereka sebagai siswa akan tetapi terdapat rasa gengsi dan gaya hidup yang sedang trend pada saat ini. Berdasarkan hasil pengamatan kepada kelas XI IPS SMA Negeri 1 Gubug dari 30 siswa, mereka hampir semuanya memiliki ponsel tidak terkecuali banyak fitur media sosial yang mereka miliki. Kemudian dari wawancara kepada 30 siswa mereka menyatakan bahwa 19 orang dari mereka suka membeli barang-barang secara online melalui media sosial. Tujuan dalam penelitian ini untuk mengetahui adakah pengaruh media sosial terhadap perilaku konsumtif, untuk mengetahui adakah pengaruh status sosial ekonomi terhadap perilaku konsumtif dan untuk Mengetahui adakah pengaruh media sosial dan status sosial ekonomi terhadap perilaku konsumtif siswa kelas XI IPS SMA Negeri 1 Gubug. Manfaat teoritis dari penelitian ini adalah untuk menambah pengetahuan dan wawasan mengenai pengaruh penggunaan media sosial dan status sosial ekonomi terhadap perilaku konsumtif siswa.

\section{LANDASAN TEORI}

\section{Media Sosial}

Media sosial adalah sebuah kelompok aplikasi berbasis internet yang membangun diatas fondasi ideologi dan teknoligi web 2.0, dan yang memungkinkan penciptaan dan pertukaran konten user-generated (Kaplan dan Haenlein 2010:61). Pendapat lain menurut Nasrullah (2017:11), media sosial adalah medium diinternet yang memungkinkan pengguna mempresentasikan dirinya maupun berinteraksi, bekerja sama, berbagi, berkomunikasi dengan pengguna lain, dan membentuk ikatan sosial secara virtual. Indikator Media sosial Menurut Anthony (2008) dalam Angraeni dan Setiaji (2018), adalah: a. Partisipasi, b.Keterbukaan, c. Percakapan, d. Masyarakat, e. Saling Terhubung. Adapun beberapa ciriciri dan manfaat menurut Kaplan dan Heinlein (2010) adalah sebagai berikut:1) Pesan yang disampaikan tidak hanya untuk satu orang saja, namun bisa ke berbagai orang. Contohnya pesan melalui sms ataupun internet. 2) Pesan yang disampaikan bebas, tanpa melalui suatu 
Gaet keeper. 3) Pesan yang disampaikan cenderung lebih cepat disbanding media lainnya. 4) Penerima pesan yang menentukan waktu interaksi.

\section{Status Sosial Ekonomi}

Status sosial ekonomi adalah posisi seseorang dalam masyarakat berkaitan dengan orang lain dalam arti lingkungan pergaulan, prestasinya dan hak-hak dalam kewajibannya dalam hubungannya dengan sumber daya. Soekanto (2012) dalam kusniawati \& kurniawan (2015). Status sosial ekonomi adalah gambaran tentang posisi seseorang atau suatu masyarakat yang ditinjau dari segi sosial ekonomi. Gambaran itu seperti tingkat pendidikan, pendapatan, dan sebagainya. Indikator menurut Suryani (2013) dalam Anggraeni dan Setiaji (2018) adalah: a) pendidikan, b) pekerjaan, c) pendapatan. Menurut Soekanto (1986:283) dalam Wahyuni (2011) pembagian pelapisan sosial ekonomi menjadi 3 gologan yaitu: 1) kelompok sosial ekonomi atas. 2) kelompok sosial ekonomi menengah, 3) kelompok sosial ekonomi bawah.

\section{Perilaku Kosumtif}

Menurut Triyaningsih (2011) perilaku konsumtif merupakan suatu perilaku atau kebiasaan yang identik dengan mengahmbur-hamburkan uang atau identik dengan membeli barang-barang yang kurang bermanfaat. Pendapat lain menurut Mowen, 2002 dalam (Wirawan, 2015) perilaku konsumtif merupakan studi tentang unit pembelian dan proses pertukaran yang melibatkan, perolehan, konsumsi dan pembuangan barang dan jasa, pengalaman serta ide-ide. Pendapat lain yang juga dikemukakan oleh (Sari, dkk, 2016) perilaku konsumtif merupakan kecenderungan seseorang untuk berperilaku secara berlebihan dalam membeli sesuatu secara irasional dan lebih mengutamakan keinginan daripada kebutuhan. Berdasarkan pendapat tersebut dapat disimpulkan bahwa perilaku konsumtif merupakan perilaku membeli dan menggunakan barang yang tidak didasarkan pada pertimbanagan dan cenderung mengkonsumsi barang tiada tanpa batas.

Indikator-indikator menurut Soemartono, 2002 dalam (Astuti, 2016) adalah: 1) Membeli produk karena iming-iming hadiah, 2) Membeli produk karena kemasannya menarik, 3) Membeli produk demi menjaga penampilan diri dan gengsi, 4) Membeli produk atas pertimbangan harga (bukan atas dasar manfaat atau kegunaannya), 5) Membeli produk hanya sekedar menjaga simbol status, 6) Memakai produk karena unsur konformitas terhadap model yang mengiklankan, 7) Munculnya penilaian bahwa membeli produk dengan harga mahal akan menimbulkan rasa percaya diri yang tinggi, 8) Mencoba lebih dari dua produk sejenis (merek berbeda)

\section{METODOLOGI}

Jenis penelitian yang digunakan dalam penelitian ini adalah penelitian kuantitatif. Subjek dalam penelitian ini adalah siswa kelas XI IPS SMA Negeri 1 Gubug. Populasi dalam penelitian ini terdiri dari 106 siswa dengan sampel sebanyak 84 siswa. Teknik pengumpulan data yaitu dengan menggunakan kuesioner dengan model berupa pernyataan. Analisis data yang digunakan yaitu dengan metode regresi linier berganda.

\section{HASIL DAN PEMBAHASAN}

1. Hasil Analisis Data

a) Uji validitas dan Reabilitas

\section{1) Pengujian Validitas}

Hasil penelitian yang valid bila terdapat kesamaan antar data yang terkumpul dengan data yang sesungguhnya yang terjdi pada objek yang diteliti. Intrumen yang valid berarti alat ukur yang digunakan untuk mendapatkan data itu valid. Valid berarti instrumen tersebut dapat digunakan untuk mengukur apa yang seharusnya diukur (Sugiyono, 2016:173). Hasil pengujian validitas selengkapnya dapat dilihat pada tabel berikut ini: 
Tabel 1. Hasil Uji Validitas Media Sosial (X1)

\begin{tabular}{lccc} 
Pertanyaan & r Hitung & r Tabel & Kesimpulan \\
\hline$X 1.1$ & 0.276 & 0,213 & Valid \\
\hline$X 1.2$ & 0.228 & 0,213 & Valid \\
\hline$X 1.3$ & 0.401 & 0,213 & Valid \\
\hline$X 1.4$ & 0.538 & 0,213 & Valid \\
\hline$X 1.5$ & 0.580 & 0,213 & Valid \\
\hline$X 1.6$ & 0.625 & 0,213 & Valid \\
\hline$X 1.7$ & 0.548 & 0,213 & Valid \\
\hline$X 1.8$ & 0.511 & 0,213 & Valid \\
\hline$X 1.9$ & 0.450 & 0,213 & Valid \\
\hline$X 1.10$ & 0.706 & 0,213 & Valid \\
\hline$X 1.11$ & 0.617 & 0,213 & Valid \\
\hline$X 1.12$ & 0.565 & 0,213 & Valid \\
\hline$X 1.13$ & 0.466 & 0,213 & Valid \\
\hline$X 1.14$ & 0.337 & 0,213 & Valid \\
\hline
\end{tabular}

Berdasarkan tabel 1 diatas, semua pernyataan dengan nomor butir 1 sampai dengan 15 memiliki nilai $r$ hitung yang lebih besar dari $r$ tabel, sehingga disimpulkan bahwa semua pernyataan tersebut valid dan pernyataan media sosial dapat digunakan untuk memperoleh data.

Tabel 2. Hasil Uji Validitas Status Sosial Ekonomi (X2)

\begin{tabular}{lccc} 
Pertanyaan & r Hitung & r Tabel & Kesimpulan \\
\hline X2.16 & 0.582 & 0,213 & Valid \\
\hline X2.17 & 0.607 & 0,213 & Valid \\
\hline X2.18 & 0.651 & 0,213 & Valid \\
\hline X2.19 & 0.548 & 0,213 & Valid \\
\hline X2.20 & 0.420 & 0,213 & Valid \\
\hline X2.21 & 0.625 & 0,213 & Valid \\
\hline X2.22 23 & 0.565 & 0,213 & Valid \\
\hline X2.24 & 0.605 & 0,213 & Valid \\
\hline X2.25 & 0.509 & 0,213 & Valid \\
\hline
\end{tabular}

Berdasarkan tabel 2 diatas, semua pernyataan dengan nomor butir 16 sampai dengan 25 memiliki nilai $r$ hitung yang lebih besar dari $r$ tabel, sehingga disimpulkan bahwa semua pernyataan tersebut valid dan pernyataan variabel status sosial ekonomi dapat digunakan untuk memperoleh data.

Tabel 3. Hasil Uji Validitas Perilaku Konsumtif $(\mathrm{Y})$

\begin{tabular}{lccc}
\hline \multicolumn{1}{c}{ Pertanyaan } & r Hitung & r Tabel & Kesimpulan \\
\hline Y.26 & 0.325 & 0,213 & Valid \\
\hline Y.27 & 0.445 & 0,213 & Valid \\
\hline Y.28 & 0.603 & 0,213 & Valid \\
\hline Y.29 & 0.470 & 0,213 & Valid \\
\hline Y.30 & 0.505 & 0,213 & Valid \\
\hline
\end{tabular}




\begin{tabular}{lccc}
\hline \multicolumn{1}{c}{ Pertanyaan } & r Hitung & r Tabel & Kesimpulan \\
\hline Y.31 & 0.541 & 0,213 & Valid \\
\hline Y.32 & 0.535 & 0,213 & Valid \\
\hline Y.33 & 0.530 & 0,213 & Valid \\
\hline Y.34 & 0.610 & 0,213 & Valid \\
\hline Y.35 & 0.526 & 0,213 & Valid \\
\hline Y.36 & 0.639 & 0,213 & Valid \\
\hline Y.37 & 0.240 & 0,213 & Valid \\
\hline Y.38 & 0.685 & 0,213 & Valid \\
\hline Y.39 & 0.704 & 0,213 & Valid \\
\hline Y.40 & 0.338 & 0,213 & Valid \\
\hline Y.41 & 0.582 & 0,213 & Valid \\
\hline Y.42 & 0.658 & 0,213 & Valid \\
\hline Y.43 & 0.271 & 0,213 & Valid \\
\hline Y.44 & 0.428 & 0,213 & Valid \\
\hline Y.45 & 0.344 & 0,213 & Valid
\end{tabular}

Berdasarkan tabel 3 diatas, semua pernyataan dengan nomor butir 26 sampai dengan 45 memiliki nilai $r$ hitung yang lebih besar dari $r$ tabel, sehingga disimpulkan bahwa semua pernyataan tersebut valid dan pernyataan perilaku konsumtif dapat digunakan untuk memperoleh data.

\section{2) Pengujian Reabilitas}

Hasil penelitian yang reliabel bila terdapat kesamaan data dalam waktu yang berbeda. Instrumen yang reliabel adalah instrumen yang bila digunakan beberapa kali untuk mengukur objek yang sama, akan menghasilkan data yang sama.

Tabel 4. Hasil Reabilitas Penelitian

\begin{tabular}{lccc}
\hline \multicolumn{1}{c}{ Variabel } & $\begin{array}{c}\text { Cronbach } \\
\text { 's Alpha }\end{array}$ & $\begin{array}{c}\text { Kriteria Cronbach's } \\
\text { Alpha }\end{array}$ & Keterangan \\
\hline Media Sosial $(\mathrm{X} 1)$ & 0.744 & 0,70 & Reliabel \\
\hline Status Sosial Ekonomi $(\mathrm{X} 2)$ & 0.747 & 0,70 & Reliabel \\
\hline Perilaku Konsumtif $(\mathrm{Y})$ & 0.846 & 0,70 & Reliabel \\
\hline
\end{tabular}

Berdasarkan data pada tabel 4 dinyatakan semua variabel reliabel karena memiliki nilai Cronbach Alpha lebih dari 0,70 dan bisa digunakan beberapa kali untuk mengukur objek yang sama serta akan menghasilkan data yang sama (konsisten).

b) Uji Asumsi Klasik

1) Uji Normalitas

Uji normalitas bertujuan untuk menguji apakah dalam model regresi variabel pengganggu atau residual memiliki distribusi normal (Ghozali, 2011:160). Hasil perhitungan uji normalitas dapat dilihat dari gambar grafik $p-p$ plot berikut ini: 


\section{Gambar 1. Hasil Uji Normalitas}

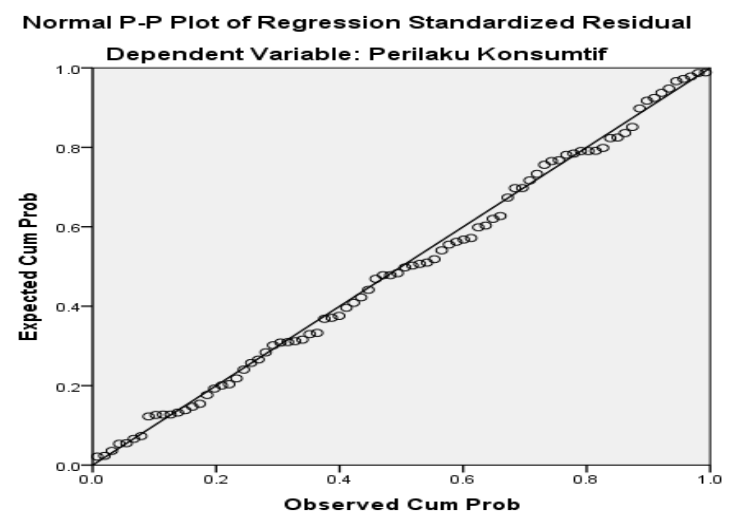

Berdasarkan grafik di atas dapat diketahui bahwa data menyebar disekitar garis diagonal dan mengikuti arah garis diagonal atau grafik histogramnya menunjukkan pola distribusi normal, maka model regresi memenuhi asumsi normalitas.

\section{2) Uji Multikolinieritas}

Uji multikolinearitas bertujuan untuk menguji apakah model regresi ditemukan adanya korelasi antar variabel independen (Ghozali, 2011:105). Hasil pengujian multikolinearitas dalam penelitian ini dapat dilihat pada tabel berikut ini.

Tabel 5. Hasil Uji Mutikolineritas Coefficients $^{a}$

\begin{tabular}{|c|c|c|c|c|c|c|c|}
\hline \multirow[t]{2}{*}{ Model } & \multicolumn{2}{|c|}{$\begin{array}{c}\text { Unstandardized } \\
\text { Coefficients }\end{array}$} & $\begin{array}{c}\text { Standardized } \\
\text { Coefficients }\end{array}$ & \multirow[t]{2}{*}{$\mathrm{T}$} & \multirow[t]{2}{*}{ Sig. } & \multicolumn{2}{|c|}{$\begin{array}{l}\text { Collinearity } \\
\text { Statistics }\end{array}$} \\
\hline & $B$ & Std. Error & Beta & & & Tolerance & VIF \\
\hline (Constant) & -3.890 & 5.855 & & -.664 & .508 & & \\
\hline Media Sosial & .855 & .149 & .502 & 5.736 & .000 & .762 & 1.312 \\
\hline $\begin{array}{l}\text { Status Sosial } \\
\text { Ekonomi }\end{array}$ & .606 & .159 & .334 & 3.813 & .000 & .762 & 1.312 \\
\hline
\end{tabular}

a. Dependent Variable: Perilaku Konsumtif

Metode untuk menguji adanya multikolinieritas dapat dilihat pada nilai tolerance dan lawannya, variance inflation factor (VIF). Dikatakan tidak terjadi multikolinieritas jika nilai tolerance $>0,1$ dan nilai VIF $<10$. Berdasarkan hasil diketahui bahwa semua variabel sudah memiliki tolerance $>0,1$ dan nilai VIF $<10$ sehingga tidak terjadi adanya multikolinieritas.

\section{3) Uji Heterokedastisitas}

Uji heteroskedastisitas bertujuan untuk menguji apakah dalam model regresi terjadi ketidaksamaan varians dari residual satu pengamatan ke pengamatan yang lain (Ghozali, 2011:139). Hasil uji heterokedastisitas dapat dilihat pada gambar berikut: 


\section{Gambar 2. Hasil Uji Heterokedastisitas}

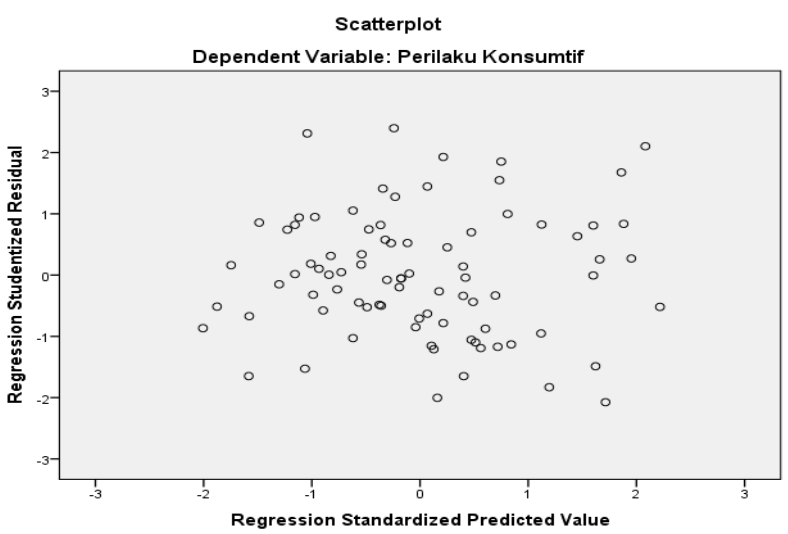

Berdasarkan grafik di atas diketahui bahwa tidak ada pola yang jelas, serta titiktitik menyebar di atas dan dibawah 0 serta tidak membentuk pola yang jelas, maka tidak terjadi heterokedastisitas.

\section{c) Analisis Regresi Linier Berganda}

Analisis regresi linier berganda bertujuan untuk mengukur hubungan variabel independen media sosial dan status sosial ekonomi terhadap perilaku konsumtif (Ghozali, 2011:95). Berdasarkan estimasi regresi liner berganda diperoleh hasil sebagai berikut:

Tabel 6. Hasil Regresi Linier Berganda

Coefficients $^{a}$

\begin{tabular}{|l|r|r|r|r|r|}
\hline Model & \multicolumn{2}{|c|}{$\begin{array}{c}\text { Unstandardized } \\
\text { Coefficients }\end{array}$} & $\begin{array}{c}\text { Standardized } \\
\text { Coefficients }\end{array}$ & \multirow{2}{*}{ S } & Sig. \\
\cline { 2 - 5 } & \multicolumn{1}{|c|}{ B } & Std. Error & \multicolumn{1}{c|}{ Beta } & & \\
\hline (Constant) & -3.890 & 5.855 & & -.664 & .508 \\
1 Media Sosial & .855 & .149 & .502 & 5.736 & .000 \\
Status Sosial Ekonomi & .606 & .159 & .334 & 3.813 & .000 \\
\hline
\end{tabular}

Berdasarkan table 6 , terdapat nilai konstanta $-3,890$, koefisien regresi $b_{1}$ sebesar $0,855, b_{2}$ sebesar 0,606 sehingga model persamaannya adalah:

$\mathrm{Y}=\mathrm{a}+\mathrm{b} 1 \mathrm{X} 1+\mathrm{b} 2 \mathrm{X} 2+\mathrm{e}$ (Arikunto, 2010:344)

Sehingga

$\mathrm{Y}=-3,890+0,855 \mathrm{X} 1+0,606 \mathrm{X} 2+\mathrm{e}$

Hasil persamaan tersebut dapat diambil penjelasan sebagai berikut:

1) Konstanta : $-3,890$ memiliki arti bahwa apabila variabel media sosial (X1), status sosial ekonomi (X2) dianggap nol atau tidak ada maka perilaku konsumtif (Y) pada siswa kelas XI IPS SMA N 1 Gubug akan memiliki nilai konstan yaitu -3,890.

2) Nilai $b_{1}: 0,855$ menunjukkan bahwa apabila nilai media sosial (X1) mengalami peningkatan sebesar 1 satuan maka perilaku konsumtif siswa kelas XI IPS SMA N 1 Gubug akan mengalami peningkatan sebesar 0,855 dengan asumsi variabelvariabel lainnya dianggap tetap.

3) Nilai $b_{2}$ : 0,606 menunjukkan bahwa apabila nilai status sosial ekonomi (X2) mengalami peningkatan sebesar 1 satuan maka perilaku konsumtif siswa kelas XI IPS SMA N 1 Gubug akan mengalami peningkatan sebesar 0,606 dengan asumsi variabel-variabel lainnya dianggap tetap. 


\section{d) Uji Hipotesis}

\section{1) Uji Simultan (F)}

Uji F digunakan untuk mengetahui apakah variabel-variabel ndependen secara simultan berpengaruh signifikan terhadap variabel dependen (Ghozali, 2011:98). Hasil Uji F adalah sebagai berikut:

Hasil Uji F
\begin{tabular}{|l|r|r|r|r|r|}
\hline ANOVA \\
\hline Model & Sum of Squares & \multicolumn{1}{|c|}{ Df } & Mean Square & F & Sig. \\
\hline Regression & 3594.064 & 2 & 1797.032 & 45.108 & $.000^{\mathrm{b}}$ \\
Residual & 3226.936 & 81 & 39.839 & & \\
Total & 6821.000 & 83 & & & \\
\hline
\end{tabular}
b. Dependent Variable: Perilaku Konsumtif
b. Predictors: (Constant), Status Sosial Ekonomi, Media Sosial

Uji F digunakan untuk mengetahui pengaruh variabel Media sosial (XI) dan Status Sosial ekonomi (X2) terhadap perilaku konsumtif (Y) secara serentak/ bersamasama. Dikatakan ada pengaruh jika nilai signifikansi kurang dari 0,05 atau $F$ hitung lebih besar dari $\mathrm{F}$ tabel. Berdasarkan hasil di atas diperoleh nilai signifikansi sebesar $0,000<0,05$ dan $F$ hitung sebesar 45,108 > F tabel 3,11. Maka secara simultan variabel berpengaruh media sosial (X1) dan status sosial ekonomi (X2) terhadap perilaku konsumtif $(\mathrm{Y})$.

\section{2) Uji Parsial (t)}

Uji t bertujuan untuk mengetahui seberapa jauh pengaruh satu variabel penjelas secara individual dalam menerangkan variasi variabel dependen. Pengujian yang dilakukan terhadap hipotesis yang diajukan digunakan untuk menguji variable bebas dan variable terikat (Ghozali, 2011:98-99). Hasil dari pengujian tersebut terdapat pada tabel 6, adalah sebagai berikut:

a. Variabel media sosial (X1) memiliki nilai t hitung sebesar 5,736, dengan tingkat signifikansi 0,000 . Karena nilai $t$ hitung 5,736 > t tabel 1,980 dan tingkat signifikansi sebesar $0,000<0,05$, sehingga dapat disimpulkan bahwa media sosial memiliki berpengaruh signifikan terhadap perilaku konsumtif. Hipotesis pertama $(\mathrm{H} 1)$ yang menyatakan media sosial berpengaruh terhadap perilaku konsumtif siswa kelas X1 IPS SMA Negeri 1 Gubug dapat diterima.

b. Variabel status sosial ekonomi (X2) memiliki t hitung sebesar 3,813, dengan tingkat signifikansi sebesar 0,000 . Karena nilai t hitung 3,813 >t tabel 1,980 dengan signifikansi sebesar $0,000<0,05$, dapat disimpulkan bahwa status sosial ekonomi berpengaruh dan signifikan terhadap perilaku konsumtif siswa kelas XI IPS SMA N 1 Gubug. Hipotesis kedua $(\mathrm{H} 2)$ yang menyatakan status sosial ekonomi berpengaruh terhadap perilaku konsumtif siswa kelas XI IPS SMA N 1 Gubug dan dapat diterima.

\section{3) Koefisien Determinasi $\left(\mathbf{R}^{2}\right)$}

Uji koefisien determinasi digunakan untuk mengetahui besaran dalam persen pengaruh variabel independen secara keseluruhan terhadap variabel dependen (Ghozali, 2011: 97). Hasil uji koefisien determinasi dalam penelitian ini dapat dilihat pada tabel berikut: 
Tabel 7. Uji Determinasi $\mathbf{R}^{2}$

\begin{tabular}{|l|r|r|r|c|}
\hline \multicolumn{5}{|c|}{ Model Summary } \\
\hline 1 & $\mathrm{R}$ & $\mathrm{R}$ Square & $\begin{array}{c}\text { Adjusted R } \\
\text { Square }\end{array}$ & $\begin{array}{c}\text { Std. Error of the } \\
\text { Estimate }\end{array}$ \\
\hline
\end{tabular}

a. Predictors: (Constant), Status Sosial Ekonomi, Media Sosial

Berdasarkan tabel 4.9 Nilai RSquare $\left(R^{2}\right)$ sebesar 0,527 artinya besar kontribusi variabel $X$ (independent) yaitu media sosial dan status sosial ekonomi terhadap variabel $Y$ (dependent) perilaku konsumtif adalah sebesar 52,7\% sedangkan sisanya sebesar 47,3\% (100\%-52,7\%) dipengaruhi faktor lain.

\section{Pembahasan}

\section{a. Pengaruh Media Sosial Terhadap Perilaku Konsumtif}

Hipotesis pertama menunjukkan bahwa variabel media sosial memberikan pengaruh terhadap perilaku konsumtif siswa kelas XI IPS SMA N 1 Gubug. Nilai koefisien regresi sebesar 0,855 dengan nilai signifikansi sebesar $0,000<0,05$ yang artinya berpengaruh signifikan terhadap perilaku konsumtif siswa. Hal ini berarti semakin meningkatnya tingkat penggunaan media sosial maka akan semakin mempengaruhi perilaku konsumtif siswa kelas XI IPS SMA Negeri 1 Gubug.

b. Pengaruh Status Sosial Ekonomi Terhadap Perilaku Konsumtif

Variabel status sosial ekonomi dalam penelitian ini memberikan pengaruh terhadap perilaku konsumtif siswa kelas XI IPS SMA Negeri 1 Gubug dengan koefisien regresi sebesar 0,606 dengan tingkat signifikansi sebesar 0,000<0,05 artinya berpengaruh signifikan terhadap perilaku konsumtif siswa.

c. Pengaruh Media Sosial dan Status Sosial Ekonomi Terhadap Perilaku Konsumtif

Variabel media sosial dan status sosial ekonomi terhadap perilaku konsumtif secara simultan memiliki pengaruh terhadap perilaku konsumtif, dan uji hipotesis telah terbukti. Berdasarkan hasil analisis data dapat diketahui nilai signifikansi uji $F$ sebesar 0,000 lebih kecil dari 0,05 . Nilai $F$ hitung sebesar 45,108 yang artinya variable media sosial dan status sosial ekonomi secara bersama-sama berpengaruh signifikan terhadap perilaku konsumtif. Hasil analisis data juga menunjukkan angka koefisien determinasi (R2) sebesar 0,572. Artinya pengaruh variabel media sosial dan status sosial ekonomi terhadap perilaku konsumtif sebesar $52,7 \%$ sedangkan sisanya $47,3 \%$ dipengaruhi oleh variabel lainnya yang tidak digunakan dalam penelitian ini. Dengan demikian dapat dikatakan bahwa tingkat kemudahan penggunaan media sosial dan dengan status sosial ekonomi orang tua yang tinggi dapat mempengaruhi perilaku konsumtif siswa. Dengan adanya media sosial dan status sosial ekonomi akan mampu merubah pola pikir dan gaya hidup seseorang untuk cenderung berperilaku konsumtif.

\section{PENUTUP}

\section{Kesimpulan}

Berdasarkan hasil penelitian dan pembahasan maka dapat diambil kesimpulan sebagai berikut:

1. Variabel media sosial secara berpengaruh positif dan signifikan terhadap perilaku konsumtif siswa kelas XI IPS SMA N 1 Gubug.

2. Variabel status sosial ekonomi berpengaruh positif dan signifiikan terhadap perilaku konsumtif siswa kelas XI IPS SMA N 1 Gubug. 
3. Variabel media sosial dan status sosial ekonomi berpengaruh signifikan terhadap perilaku konsumtif siswa kelas XI IPS SMA N 1 Gubug.

\section{Saran}

Adapun beberapa saran dari peneliti dalam penelitian yang telah dilaksanakan Bagi peneliti selanjutnya diharapkan mampu meneliti lebih mendalam lagi mengenai apa saja yang mempengaruhi tingkat konsumtif seseorang yang belum dibahas dalam penelitian ini.

\section{DAFTAR PUSTAKA}

Anggraeni, E. \& Setiaji, K. (2018). Pengaruh Media Sosial dan Status Sosial Ekonomi Terhadap Perilaku Konsumtif Mahasiswa. Economic Education Analisys Journal, Vol. 7, No. 1, Hal. 172-180.

Arikunto, S. (2010). Prosedur Penelitian Suatu Pendekatan Praktik. Jakarta: Rineka Cipta

Astuti, R. (2016). Pengaruh Status Sosial Ekonomi Orang Tua, Literasi Ekonomi dan Life Style Terhadap Perilaku Konsumsi Mahasiswa Jurusan Pendidikan Ekonomi IKIP PGRI Bojonegoro. Jurnal Edutama, Vol. 3, No. 2, Hal. 49-58.

Ghozali, I. (2011). Aplikasi Analisis Multivariat dengan Program IBM SPSS 19 Edisi 5. Semarang: Badan Penerbit Universitas Diponegoro.

Kaplan, A.M \& Heinlein, M. (2010). Ucers Of The World Unite!The Challenges and Opportunitties Of Social Media. Bussiness Horison, 59-68.

Kusniawati, M. \& Kurniawan, R. Y. (2016). Pengaruh Status Sosial Ekonomi Orang Tua dan Literasi Ekonomi Terhadap Perilaku Konsumtif Siswa Kelas X IPS SMA Negeri 2 Tuban . Jurnal Pendidikan Ekonomi, Vol. 4, No. 3, Hal. 1-9.

Miranda, S. (2017). Pengaruh Insatgram Sebagai Media Online Shopping Fashion Terhadap Perilaku Konsumtif Mahasiswi Fakultas IImu Sosial dan IImu Politik Universitas Riau. JOM FISIP, Vol. 4, No. 1, Hal. 1-15.

Nasrullah, R. (2017). Media Sosial Perspektif Komunikasi, Budaya dan Sosioteknologi. Bandung: PT. Remaja Rosdakarya Bandung.

Nikita, D. \& Hadi, N.U. (2018). Pengaruh Status Sosial Ekonomi Rumah tangga dan Lingkungan Keluarga Terhadap Perilaku Konsumtif siswa Kelas VIII SMP Negeri 1 Karangrejo Tahun Ajaran 2017/2018. Jurnal Inovasi Pendidikan Ekonomi, Vol. 8, No, 1, Hal. 15-21.

Sari, D. dkk. (2018). Pengaruh Online Shop Jejaring Sosial Terhadap Perilau Konsumtif Pada Ibu Rumah Tngga di Desa Mojo Tamping, Kecamatan Bangsal, Kabupaten Mojokerto. Jurnal Representamen, Vol. 4, Hal. 1-9.

Sugiyono. (2016). Metode Penelitian Pendidikan Pendekatan Kuantitatif, Kualitatif dan R\&D. Bandung: Alfabeta.

Triyaningsih, S. (2011). Dampak Online Marketing Melalui Facebook Terhadap Perilaku Konsumtif Masyarakat. Jurnal Ekonomi dan Kewirausahaan, Vol. 11, No. 2, Hal. $172-$ 117.

Wahyuni, S. (2011). Hubungan Status Sosial Ekonomi Orang Tua dan Pemanfaatan Media Belajar dengan Prestasi Belajar Pada Siswa Kelas X SMA Batik 2 Surakarta Tahun Ajaran 2010/2011. Skripsi. Surakata: Universitas Sebelas Maret. Tidak Diterbitkan. 
Wirawan, Y. (2015). Pengaruh Status Sosial Ekonomi Orang Tua Terhadap Prestasi Belajar dan Perilaku Konsumsi Siswa. Equilibrium, Vol. 3, No. 1, Hal. 20-28.

Yunus, M. (2018). Go-Jek Sebagai Simbol Perubahan Sosial dan Ekonomi di Kota Tegal. Equilibria Pendidikan: Jurnal Ilmiah Pendidikan Ekonomi, 2(2), 59-68. 